University of Wollongong

Research Online

Faculty of Business - Papers (Archive)

Faculty of Business and Law

$1-1-2011$

Dividend smoothing when firms distribute most of their earnings as dividends

Khamis Al-Yahyaee

Sultan Qaboos University

Toan Pham

University of New South Wales

Terry S. Walter

University of Technology Sydney, twalter@uow.edu.au

Follow this and additional works at: https://ro.uow.edu.au/buspapers

Part of the Business Commons

Research Online is the open access institutional repository for the University of Wollongong. For further information contact the UOW Library: research-pubs@uow.edu.au 


\title{
Dividend smoothing when firms distribute most of their earnings as dividends
}

\begin{abstract}
Due to its distinctive institutional background, Oman offers a valuable opportunity to investigate the stability of the dividend policy. In Oman, (1) there are no taxes on dividends, (2) firms are highly levered mainly through bank loans, (3) there is a high concentration of stock ownership and (4) there is variability in cash dividend payments. These factors suggest a diminished role of dividend smoothing in Oman. Our results show that Omani financial firms have erratic dividend policies. These results are inconsistent with the predictions suggested by the relatively weak corporate governance, government ownership and dividend signalling.
\end{abstract}

Disciplines

Business

Publication Details

Al-Yahyaee, K. H., Pham, T. M. \& Walter, T. S. (2011). Dividend smoothing when firms distribute most of their earnings as dividends. Applied Financial Economics, 21 (16), 1175-1183. 


\title{
Dividend smoothing when firms distribute most of their earnings as dividends
}

\author{
K. H. Al-Yahyaee ${ }^{\mathrm{a},{ }^{*}}$, T. M. Pham ${ }^{\mathrm{b}}$, T. S. Walter ${ }^{\mathrm{c}}$ \\ ${ }^{a}$ Department of Economics and Finance, College of Commerce and Economics, Sultan Qaboos \\ University, Sultanate of Oman \\ *Corresponding Author. E-mail: yahyai@squ.edu.om \\ ${ }^{b}$ School of Banking and Finance, Australian School of Business, University of New South Wales, \\ Australia \\ ${ }^{c}$ School of Finance and Economics, University of Technology Sydney, Australia
}

Due to its distinctive institutional background, Oman offers a valuable opportunity to investigate stability of dividend policy. In Oman, (1) there are no taxes on dividends, (2) firms are highly levered mainly through bank loans, (3) there is a high concentration of stock ownership, and (4) there is variability in cash dividend payments. These factors suggest a diminished role of dividend smoothing in Oman. Our results show that Omani financial firms have erratic dividend policies. These results are inconsistent with the predictions suggested by the relatively weak corporate governance, government ownership, and dividend signaling. 


\section{Introduction}

It is well documented that firms in the US smooth their dividends. In s well cited study, Lintner (1956) shows that US companies have stable dividend policies. He finds that managers are reluctant to raise (cut) dividends immediately following an increase (decrease) in earnings. Hence, changes in dividends appear to lag changes in

earnings by a number of periods. Subsequent research by Fama and Babiak (1968), Brav et al. (2005), and Aivazian et al. (2006) confirm Lintner's original findings. Using data from the UK, Michaely and Roberts (2007) report that dividend smoothing is more pronounced in public firms relative to private firms where potential agency issues and information asymmetries are more pronounced. More recently, Leary and Michaely (2009) find that dividend smoothing has been increasing over the past 50 years, suggesting that managers are more concerned about dividend smoothing today.

The majority of these studies are conducted using US data. One natural question is whether these dividend effects are peculiar to the US or if they are also prominent in countries where the tax regime and/or institutional and economic characteristics are significantly different. The purpose of this paper is to examine whether Omani financial firms smooth their dividends by applying the Lintner's partial adjustment model. We also examine whether Omani financial firms have a long-term target payout ratio.

The financial sector plays a crucial role in economic development in Oman. The contribution of the financial sector to the Gross Domestic Product occupies second place after oil and gas. The importance of the financial sector can also bee seen from its representation in the stock market which represents $51 \%$ of market capitalization in 2008. The financial sector has the highest liquidity with the highest number of shares 
traded in the Muscat Securities Market (MSM). The sector accounts for 59\% of shares traded and 45\% of total profits of MSM-listed firms in 2008.

Several important economic and institutional features make Oman a unique and interesting environment in which to examine the stability of dividend policy. There are reasons that may suggest Omani financial firms may adopt a smoothing dividend policy and there are other reasons that may suggest otherwise. First, Omani firms pay a large proportion of their earnings through dividends. This is very different from the western countries which are known to distribute moderate dividends. Omani investor's attitude towards dividends may contribute to the higher payout ratio. Most investors in Oman consider dividends as the principal component of stock returns (Al-Yahyaee, 2006)

Second, there are no taxes on dividends in Oman. This is very different from Western countries which have been traditionally taxing dividends at a higher rate than capital gains. The absence of taxes in Oman may have an impact on dividend stability. Rozycki (1997) shows that personal income taxes provide managers with a motivation to smooth the dividend payments. He provides evidence that dividend smoothing has increased the wealth for a tax paying investor by reducing the present value of the investor's future expected income tax liabilities. Consequently, the absence of personal income taxes is expected to reduce the importance of dividend stability in Oman.

Third, Omani companies rely heavily on bank financing (Al-Yahyaee, 2006). Aivazian et al. (2003a) suggest that bank debt reduce that the moral hazard problem and the agency problem. ${ }^{1}$ Aivazian et al. $(2003 \mathrm{~b}, 2006)$ argue that dividend stability should be less important in bank centric countries like Oman because bank debt

\footnotetext{
${ }^{1}$ See Aivazian et al. (2003a) for a discussion on the role of bank debt in reducing the agency cost. Fleming, Heaney, and McCosker (2005) also provide a discussion of the benefits of debt financing in alleviating the agency problem.
} 
reduces the value of agency reduction roles typically fulfilled by dividend payments. Dewenter and Warther (1998) also suggest that dividend stability may not be important for companies that rely on bank debt due to bank monitoring. Hence, the reliance of Omani firms on bank debt financing implies that dividend stability may not be important for Omani firms.

However, there are reasons that may suggest that banks in Oman may be relatively ineffective in monitoring. Saidi and Kumar (2008) suggest that corporate governance in Oman is relatively weak. They demonstrate that banks in Arab Gulf Cooperation Council (GCC) countries including Oman play limited role in scrutinizing corporate governance practices of borrowers. ${ }^{2}$ Saidi and Kumar (2008) indicate that there is a relatively weaker institutional characteristic in the GCC countries including Oman in terms of disclosure and transparency requirements, creditor rights, enforcement of contracts, regulations, oversight, and minority shareholder rights. Mohamed et al. (2008) find that many Omani firms do not comply with the Code of Corporate Governance. ${ }^{3}$ They observe that the implementation, monitoring, and enforcement aspects of the corporate governance regulatory regime are still at a nascent stage. ${ }^{4} \mathrm{La}$ Porta et al. (1998) claim that the lack of transparency, inadequate legal infrastructure, and weak investment protection in emerging markets all enhance the role of dividends as a reputation mechanism. In this case, and even with the close banking relations and closely held nature of firms, dividend payment is extremely important to attract capital (Aivazian et al., 2003b). The relatively weak institutional variables and the relative noncompliance with corporate governance codes may reduce the

\footnotetext{
${ }^{2}$ GCC countries include United Arab Emirates, Kuwait, Oman, Saudi Arabia, Qatar, and Bahrain.

${ }^{3}$ The Capital Market Authority (CMA) in June 2002, published its Corporate Governance Code (Circular No. 11/2002), which was later amended and replaced by Circular No. 1/2003 of April 2003. The Code requires all listed companies to publish a section on corporate governance in their annual financial statements. This Code is not as elaborate as corporate governance regimes in western countries (Mohamed et al., 2009)

${ }^{4}$ See Mohamed et al. (2008) for a detailed description of Corporate Governance in Oman.
} 
effectiveness of banks in monitoring firms. This may suggest that the impact of bankcentricity on dividend stability may be relatively ineffective in Oman. The relatively weak governance practices in Oman may induce firms to pay out more dividends to offset the weak monitoring through corporate governance mechanism. John and Knyazeva (2008) claim that firms will use payout policy to mitigate the agency conflict due to poor governance. They argue that poor corporate governance exacerbates the agency costs of free cash flow. Hence, a higher level of dividends is necessary to impose a constraint on the manager. Consistent with their proposition, John and Knyazeva (2008) find that firms with weak corporate governance are more likely to pay higher dividends. Similarly, Knyazeva (2008) shows that weakly governed managers engage in more dividend smoothing and pay high dividends.

Fourth, Omani firms are owned by a small number of investors who have controlling interests. Al-Yahyaee et al. (2009) show that the average ownership of MSM-listed firms by shareholders who own at least ten percent of the issued capital is 52 percent. A significant part of this ownership belongs to the government. In fact, Al-Yahyaee (2006) shows that government ownership is a significant factor that affects dividend policy in Oman. Government-controlled firms are expected to suffer most from agency problem as they are ultimately owned by the citizens (Gugler, 2003). As most citizens are only indirect shareholders of government-controlled firms, they have few incentives to monitor the management. Consequently, the managers of government-controlled firms will prefer a stable dividend policy with high dividends to keep their principals happy. Gugler (2003) examines the potential impact of a range of different types of shareholders on dividends for a sample of Austrian firms and report evidence that government-controlled firms have the highest dividend payout and practice dividend smoothing. Hence, the higher dividend payout 
and the stability of dividends in Oman may be the consequence of corporate control. The high government ownership in Oman implies that the potential agency problem is likely to be high due to the few incentives of the shareholders (government) to monitor the management. Consequently, dividends in Oman may serve as a corporate governance device bonding managers to generate sufficient cash flow to honor the precommitted level of dividends. Therefore, firms in Oman are more likely to pay high dividends and follow stable dividend policies.

Fifth, Omani firms appear to use dividends to signal their future prospectus (AlYahyaee et al., 2009). The dividend signaling theory is based on the belief that investors prefer stable dividend over the years and firms are reluctant to cut dividends. John and Williams (1985) show that, in equilibrium, the optimal dividend policy is to pay smoothed dividends relative to stock prices. Their model implies that when dividends are used as a signaling mechanism firms are expected to smooth their dividends. In a similar vein, Guttman et al. (2008) show that dividend smoothing can arise from a coarse signaling equilibrium in a setting where managers have private information about firm value. Al-Yahyaee et al. (2009) find that Omani firms use dividends to signal their future prospects. Dividends are smoothed with respect to earnings to be a credible signal (Jeong, 2008). This may suggest that Omani firms use dividends as a signal to convey their private information to outsiders. Hence, Omani firms are more likely to smooth their dividends to strengthen the credibility of dividends as a signal of firm's future prospects.

Finally, a feature of Omani MSM-listed firms is their variability in cash dividend payments. The majority of Omani firms change their dividends almost every year. This practice contrasts with patterns observed in the US and other developed countries, where most stocks experience relatively few changes in their dividends. In 
fact, Aharony and Swary (1980) find that about $87 \%$ of sampled firms had no change in quarterly dividend payments in the U.S during the period January 1963 to December 1976. In the data sampled by Bajaj and Vijh (1990), more than $80 \%$ of announcements made between July 1962 and June 1987 involve no change in dividends. More recently, Hallock and Mashayekhi (2006) find that $80 \%$ of firms do not change their dividends in the US during the period 1970-2000. The variability of dividends may suggest a diminished role of dividend stability in Oman.

Whether or not dividends are stable in Oman is an empirical question. While studies in developed markets show that firms smooth dividends, the picture is less clear in Oman. On the one hand, the relatively weak corporate governance, government ownership, and dividend signaling all suggest that firms may have stable dividend policies. On the other hand, high bank leverage, the absence of taxes and the variability in cash dividend payments may suggest that firms may have unstable dividend policies. Whether the net effect of these factors on dividend stability is positive or negative is an empirical issue.

Our research provides a number of interesting results on stability of dividend policy. First, we find that Omani financial firms have unstable dividend policies. This instability of dividends support the predictions suggested by the high bank leverage, absence of taxes, and the variability of dividend payments in Oman. Second, our evidence shows that Omani financial firms are not reluctant to cut dividends. Third, we find that financial firms do have a target dividend payout ratio that they move quickly towards.

In general, our results stand in sharp contrast to the evidence reported using US data where firms adopt a policy of smoothing dividends and are reluctant to cut them. These results suggest that the institutional and economic environment play an 
important role in determining the smoothing behavior of firms. Our findings show that there are differences in dividend policies between the Omani companies and those in developed markets. Consequently, potential investors in the Omani market should be aware about these differences in making their investment decisions. This study also highlights the need for further research in order to examine whether these results have any effect on dividend initiations and omissions in Oman.

The remainder of the paper proceeds as follows. Section 2 describes the Lintner Model. Section 3 describes the institutional aspects of the Omani stock market. Section 4 describes the data and presents summary statistics for the payment of dividends, and reports some descriptive statistics for the sample. In section 5 we examine the stability of dividends using the Lintner model. Section 6 concludes the paper.

\section{The Lintner Model}

In a frequently cited study, Lintner (1956) develops a quantitative model to test for the stability of dividend policy where he hypothesizes the following relationship between dividends and earnings:

$$
D^{*}{ }_{t}=r E_{t}
$$

where $D^{*}{ }_{t}$ is the target level of dividends for any year $t, r$ is the target payout ratio, and $E_{t}$ is the firm's net earnings in year $t$. In addition, Lintner (1956) also predicts that a firm will only partially adjust to the target dividend level in any given year, so the change in dividend payments from year $t-1$ to year $t$ is given by:

$$
D_{t}-D_{t-1}=\alpha+c\left(D^{*}{ }_{t}-D_{t-1}\right)+u_{t}
$$


where $\alpha$ is the intercept term, $c$ is the speed of adjustment coefficient, $u$ is the error term, $D^{*}{ }_{t}$ is the target dividend payment in period $t, D_{t}$ is the actual dividend payment in period $t$ and $D_{t-1}$ is the actual dividend payments in period $t-1$.

Substituting $r E_{t}$ for the target dividend payment $\left(D^{*}{ }_{t}\right)$ in equation (2), we arrive at the following model,

$D_{t}-D_{t-1}=\alpha+\beta_{1} E_{t}+\beta_{2} D_{t-1}+u_{t}$

where $\beta_{1}=$ cr and $\beta_{2}=-\mathrm{c}$.

The constant term $(\alpha)$ is expected to have a positive sign "to reflect the greater reluctance to reduce than to raise dividends" Lintner (1956, p. 107). The speed of adjustment coefficient (c) reflects that stability of dividends and measures the speed of adjustment toward the target payout ratio $(r)$ in response to earnings changes. The value $c$ reflects the dividend smoothing behaviour of firms to changes in the level of earnings. A higher value of $c$ indicates less dividend smoothing and vice versa. Thus, a conservative firm will have a lower adjustment rate, while a less conservative firm will have a higher adjustment rate.

As shown by Lintner, equation (3) can be rewritten as:

$$
D_{t}=\alpha+c r E_{t}+(1-c) D_{(t-1)}+u_{t}
$$

This model implies that firms set their dividends in accordance with current level of earnings, and that changes in dividends do not correspond exactly with the changes in earnings.

To test whether dividend policy in Oman is stable, we follow Fama and Babiak (1968) and use earnings per share (EPS) and dividends per share (DPS) rather than total earnings as follows:

$D P S_{t}=\alpha+\beta_{1} D P S_{t-1}+\beta_{2} E P S_{t}+u_{t}$ 
where $D P S_{t}$ is the dividend per share for period $t, E P S_{t}$ is the earning per share for period $t$, and $u$ is the error term. Fama and Babiak argue that per share data are more appropriate for this test than the aggregate data used by Lintner. Indeed, almost all studies conducted since Lintner's study employ per share data rather than aggregate data. This model has been used by many scholars to examine the stability of dividends such as Brittan (1964, 1966), Fama and Babiak (1968), Fama (1974), Dewnter and Warther (1998), Adaoglu (2000), Aivazian et al. (2003a), Omet (2004), Naceur et al. (2006), Michaely and Roberts (2007), Leary and Michaely (2009), among others.

\section{Oman Stock Market: Institutional Aspects}

\section{Trading rules and practices}

Oman is a small free market economy with a stable social, political, and economic system, low taxation rates, steady economic growth, low inflation, a manageable level of external debt, fairly liberal investment laws, a sustainable level of budget deficit, and no controls over capital movements. In Oman, firms are subject to market economy discipline that is comparable to Western firms. ${ }^{5}$

Trading in the MSM was computerized in 1997. MSM is a pure auction market where trades are facilitated through brokerage firms. It is very different from the NYSE in that there are no specialists or market makers. Trading in the market is conducted by stockbrokers, who can not trade on their own account, which means that they have no role in setting cum- and ex-day prices. Orders are initiated from brokerage firms via computer terminals in their offices or on the exchange floor. Brokerage firms match buy and sell orders. Investors intending to buy or sell stocks execute their transactions through these brokerage firms that charge them a

\footnotetext{
${ }^{5}$ See Al-Yahyaee (2006) for details on this issue.
} 
commission or transaction fees. The minimum fee that can be charged by a brokerage firm is $0.4 \%$ and the maximum is $0.75 \%(0.015 \%$ of the fee is revenue for the MSM).

As Oman is a petroleum-producing country, taxes play a minor role in generating income for the economy (Al-Yahyaee et al., 2008). As a result, shareholders are not subject to any taxes on dividends. Likewise, there are no taxes on capital gains. The only taxes are the $12 \%$ flat tax rate on corporate income. This makes the tax system in Oman one of the simplest in the world.

\section{Dividends}

Firms listed at the MSM distribute dividends in two forms namely, cash dividends and stock dividends. Paying dividends in one form or another is not compulsory. If the board of directors proposes to distribute dividends, the details must be published in the daily newspapers. The proposed dividend is subject to the final approval of shareholders at the Annual General Meeting (AGM). Generally, most dividend propositions are accepted at the AGM as the board of directors usually represents the majority of the share capital. The date when the AGM is held is the record date. Investors whose names are recorded as stockholders on this date are entitled to receive the declared dividend. The following date is the ex-dividend date. Firms usually pay dividends once a year. Some firms complement their cash dividends with stock dividends.

\section{Data}

The data for this study are obtained from "Share-Holding Guide of MSM Listed Companies" published by the MSM. As the data were available in hard copy only, the 
first task was to input the data into a computer database. The data set comprise all publicly traded financial firms listed at the MSM.

These data are time series cross-sectional variables which are collected over the entire life of the MSM from 1989 to 2004 . We check the accuracy of the data by comparing the figures from the MSM Guide with the data from the firm's financial statements available on the internet, where possible.

The empirical literature on stability dividend policy has largely ignored firms that do not pay dividends. If value-maximizing firms choose not to pay dividends, a sample that contains only dividend paying firms will be subject to a selection bias. An econometric analysis of such a sample will yield biased and inconsistent estimates. To address this selection bias, we use both dividend-paying and nondividend paying firms. In this vein, Kim and Maddala (1992) demonstrate that it is important to allow for zero observations on dividends in the estimation of models of dividend behavior. Likewise, Deshmukh (2003, p. 353) states "If firms find it optimal to not pay dividends, then their exclusion from any empirical analysis may create a selection bias in the sample, resulting in biased and inconsistent estimates of the underlying parameters". 6

\section{Estimation model}

We examine the stability of dividend behavior in Oman using the Lintner model. Since there are some firms in Oman that do not pay dividends, this creates a censoring problem which needs to be addressed in estimating the Lintner model. In this case, previous research suggested the use of the Tobit model (Anderson, 1986; Kim and

\footnotetext{
${ }^{6}$ For further information on this issue, see Anderson (1986) and Kim and Maddala (1992).
} 
Maddala, 1992; Huang, 2001a, 2001b). We use a Tobit model to test the stability of dividends in Oman. ${ }^{7}$

Payment of dividends

Omani firms tend to attract investors by distributing large dividends (Al-Yahyaee, 2006). Most of the profitable Omani firms distribute dividends as a means of rewarding investors for holding their securities. Stock repurchase is a rare phenomena in Oman, however some firms supplement their cash dividends distributions with stock dividends.

In Oman, most profitable companies a high proportion of their profits through cash dividends. This led the CMA to issue a circular (number 12) that requires firms to have a clear policy of dividends and to disclose it in their financial reports. With this regard, the circular states that

“...studies have shown that the majority of Omani public joint stock companies currently operate with a dividend cover of $100 \%$ of its available profits assigned to dividends...We are all required to set out a clear cut dividend policy with a view to the long term expansion of the company by striking the right mix to meet both good housekeeping practice (retention of some earnings appropriate to the economic conditions) and the understandable desire of shareholders for immediate returns. CMA calls upon public joint stock companies to adopt prudent policies in cash dividends and to disclose the same in the annual report of the board of directors attached to the financial statements."

Table 1. Dividend payout ratio for Omani financial firms over the period 19892004

Panel A: All firms

\begin{tabular}{|l|l|l} 
Year & Mean & SD
\end{tabular}

\footnotetext{
${ }^{7}$ As a robustness check, we also use a random effects tobit regression. The tobit and random effects tobit results are very similar to those reported using Tobit regressions.
} 


\begin{tabular}{|c|cc|}
\hline 1989 & $47 \%$ & $30 \%$ \\
1990 & $94 \%$ & $279 \%$ \\
1991 & $49 \%$ & $47 \%$ \\
1992 & $32 \%$ & $39 \%$ \\
1993 & $46 \%$ & $35 \%$ \\
1994 & $45 \%$ & $34 \%$ \\
1995 & $49 \%$ & $49 \%$ \\
1996 & $37 \%$ & $35 \%$ \\
1997 & $19 \%$ & $30 \%$ \\
1998 & $20 \%$ & $31 \%$ \\
1999 & $25 \%$ & $59 \%$ \\
2000 & $24 \%$ & $49 \%$ \\
2001 & $15 \%$ & $30 \%$ \\
2002 & $33 \%$ & $52 \%$ \\
2003 & $60 \%$ & $142 \%$ \\
2004 & $58 \%$ & $139 \%$ \\
\hline Overall period & $41 \%$ & $67 \%$ \\
\hline Observations & \multicolumn{2}{|c}{} \\
\hline
\end{tabular}

Panel B: Dividend paying firms

\begin{tabular}{|c|cc|}
\hline Year & Mean & SD \\
\hline 1989 & $60 \%$ & $19 \%$ \\
1990 & $149 \%$ & $343 \%$ \\
1991 & $80 \%$ & $32 \%$ \\
1992 & $72 \%$ & $18 \%$ \\
1993 & $65 \%$ & $20 \%$ \\
1994 & $62 \%$ & $22 \%$ \\
1995 & $70 \%$ & $44 \%$ \\
1996 & $58 \%$ & $26 \%$ \\
1997 & $43 \%$ & $32 \%$ \\
1998 & $55 \%$ & $25 \%$ \\
1999 & $96 \%$ & $81 \%$ \\
2000 & $70 \%$ & $62 \%$ \\
2001 & $49 \%$ & $37 \%$ \\
2002 & $55 \%$ & $58 \%$ \\
2003 & $123 \%$ & $187 \%$ \\
2004 & $138 \%$ & $189 \%$ \\
\hline Overall period & $78 \%$ & $75 \%$ \\
\hline Observations & \multicolumn{2}{|c|}{261} \\
\hline
\end{tabular}

Notes: The table presents the mean and the standard deviation for financial firms listed at the MSM for each year from 1989-2004. In panel A, we present the results for all firms including both dividend paying and non-paying firms. In panel $\mathrm{B}$, we report the results for dividend paying firms.

As with other Arab countries, Omani investors seem to prefer to receive periodic income in the form of dividends (Bolbol and Omran, 2004). For the entire sample, Panel A of Table 1 shows that the average payout ratio is around $41 \%$. When the zero dividend observations are removed, the average payout ratio increases to $78 \%$ (Panel 
B). This is much higher than the payout ratio reported by Fazzari, Hubbard, and Petersen (1988), Kaplan and Zingales (1997), and Aivazian et al. (2006) samples of US firms. It is also higher than 23.3\% reported by Chen and Dhiensiri (2009) for New Zealand.

\section{Empirical Results}

The results presented in Table 2 show that both the coefficients on lagged DPS and EPS are statistically significant with a positive sign. But the generally higher coefficient and the associated $t$-statistic of the lagged DPS imply the greater importance of past dividend in deciding the dividend payment. These results are consistent with Lintner and suggest that the lagged DPS and EPS are important factors that affect the decision to pay dividends. The coefficient on the constant is also statistically significant with a negative sign. ${ }^{8}$ This indicates that Omani firms are not reluctant to cut dividends, inconsistent with Lintner (1956).

The objective of using the Lintner model in this paper is to examine whether Omani firms follow stable dividend policies. Consequently, we are interested in the speed of adjustment. The speed of adjustment reflects how quickly the firms adjust dividends towards the target ratio; the higher the speed of adjustment, the less the smoothness, and the less stability in dividends. In our case, the speed of adjustment is 0.9412 which indicates that Omani firms have not smooth their dividends. Rather, they change their dividends frequently. These results are in line with that reported by Esteban and Pérez (2001) where they find that the speed of adjustment for European financial firms over the period 1992 to 1998 is 0.76 . They are also consistent with those reported by Naceur et al. (2006) for Tunisian firms which ranged between 0.68

\footnotetext{
${ }^{8}$ The negative constant reported in this paper is consistent with the results documented by Kim and Maddala (1992) and Huang (2001a, 2001b) who utilize Tobit regression to estimate the Lintner model.
} 
and 1.56. However, our speed of adjustment is higher than the 0.49 reported by Bodla et al. (2009) for Indian financial firms.

Table 2. Lintner model estimates

\begin{tabular}{lll}
\hline Variable & Coefficient & $T$-Statistic \\
\hline$C$ & $-0.1457^{* * *}$ & -7.3644 \\
$D P S_{-1}$ & $0.0588^{* * *}$ & 2.7855 \\
$E P S$ & $0.5335^{* * *}$ & 46.8658 \\
\hline Observations & & 377 \\
Log Likelihood & & -142.8506 \\
Wald Test $\left[\chi^{2}(2)\right]^{\mathrm{a}}$ & & 509.3700 \\
$P$-value & & 0.0000 \\
\hline
\end{tabular}

Notes: We estimate Tobit regression for financial firms listed at the MSM over the period 1989-2004. The dependent variable is the dividend per share. The explanatory variables are the lagged DPS and the current EPS. The table shows the variable, their coefficients, and their corresponding $t$-statistics. $(*)$, $(* *)$, and $(* * *)$ represents significance at the $10,5,1$ percent levels, respectively. The number in parenthesis in the Wald test represents the degrees of freedom.

Another variable of interest is whether Omani financial firms have a target payout ratio or not. Lintner (1956) hypothesizes that firms set a long-term target payout ratio and move gradually towards the target. We calculate the target payout ratio and find that Omani financial firms have a target payout ratio of $0.5668 .^{9}$ This finding indicates that financial firms do have a target dividend payout ratio that they move quickly towards. Our target payout ratio is higher than the 0.27 reported by Naceur et al. (2006) for Tunisian financial firms and the 0.135 reported by Bodla et al. (2007) for Indian firms, but smaller than the 0.85 reported by Esteban and Pérez (2001) for European firms.

\section{Conclusion}

The extensive literature on dividend policy of US firms shows that firms adopt a policy of smoothing dividends. Further, managers tend to set along-term target payout ratios and are reluctant to cut dividends. We investigate whether these stylized facts

\footnotetext{
${ }^{9}$ We calculate the target payout ratio as (the coefficient on EPS divided by the speed of adjustment).
} 
also hold for Omani financial firms which operate in a substantially different institutional and corporate governance regime which is characterized by the absence of taxes on dividends, high dividend payments, concentrated ownership, relatively weak corporate governance, and high bank debt financing. We use a panel data on a sample of Omani firms and take account of the zero observations using Tobit models.

Regarding the speed of adjustment of dividends towards the long-term target payout ratio, our results show that Omani financial firms adjust their dividend policies very quickly and they are willing to cut their dividends. These results suggest that Omani financial firms have unstable dividend policies. The results lend support to the propositions put forward by the high bank leverage, absence of taxes, and the variability of dividend payments in Oman. Our results also show that Omani firms have target payout ratios and they move quickly towards.

Our findings show that there are differences in dividend policies between the Omani companies and those in developed markets. Consequently, potential investors in the Omani market should be aware about these differences in making their investment decisions. This study also highlights the need for further research in order to examine whether these results have any effect on dividend initiations and omissions in Oman.

\section{Acknowledgments}

We are grateful to participants at the $16^{\text {th }}$ Annual Australasian Banking and Finance Conference for valuable comments and suggestions. We also thank the participants at the European Economics and Finance Society Conference in Prague for their comments and insights.

\section{References}


Adaoglu, C. (2000) Instability in the dividend policy of the Istanbul Stock Exchange (ISE) corporations: evidence from an emerging market, Emerging Market Review, 1, 252-270.

Aharony, J., and Swary, I. (1980) Quarterly dividend and earnings announcements and stockholders return: an empirical analysis, Journal of Finance, 35, 1-12.

Aivazian, V., Booth, L. and Cleary, S. (2003a) Dividend policy and the organization of capital markets, Journal of Multinational Financial Management, 13, 101-121.

Aivazian, V., Booth, L. and Cleary, S. (2003b) Do emerging market firms follow different dividend policies from the U.S. firms?, Journal of Financial Research, 26, 371-387.

Aivazian, V., Booth, L. and Cleary, S. (2006) Dividend smoothing and debt ratings, Journal of Financial and Quantitative Analysis, 41, 439-453.

Al-Yahyaee, K., (2006) Capital structure and dividend policy in a personal tax free environment: the case of Oman, Unpublished Ph.D. Dissertation, University of New South Wales, Australia.

Al-Yahyaee, K., Pham, T. and Walter, T. (2008) Ex-Dividend day behavior in the absence of taxes and price discreteness, International Review of Finance, 8, 103123.

Al-Yahyaee, K., Pham, T. and Walter, T. (2009) The information content of cash dividend announcements in a unique environment, Journal of Banking and Finance, forthcoming.

Anderson, G. (1986) An application of the Tobit model to panel data: modelling dividend behaviour in Canada, Working Paper No. 85-22, McMaster University, Canada.

Bajaj, M. and Vijh, A. (1995) Trading behavior and the unbiasedness of the market reaction to dividend announcements, Journal of Finance, 50, 255-279.

Baltagi, B. (2001), Econometric Analysis of Panel Data, $2^{\text {nd }}$ ed. John Wiley and Sons, New York.

Bodla, B., Pal, K. and Sura, S. (2007) Examining application of Lintner's dividend model in Indian banking industry, ICFAI Journal of Bank Management, 6, 40-59.

Bolbol, A. and Omran, M. (2004) Arab stock markets and capital investment, Working Paper, Arab Monetary Fund, United Arab Emirates.

Brav, A., Graham, J., Harvey, C. and Michaely, R. (2005) Payout policy in the $21^{\text {st }}$ century, Journal of Financial Economics, 77, 483-527.

Brittain, J. (1964) The tax structure and corporate dividend policy, American Economic Review, 54, 272-287. 
Brittain, J. (1966) Corporate Dividend Policy. Brookings Institution, Washington DC.

Chen, J. and Dhiensiri, N. (2009) Determinants of dividend policy: the evidence from New Zealand, International Research Journal of Finance and Economics, 34, 1828.

Deshmukh, S. (2003) Dividend initiations and asymmetric information: a hazard model, The Financial Review, 38, 351-368.

Dewenter, K. and Warther, V. (1998) Dividends, asymmetric information, and agency conflicts: evidence from a comparison of the dividend policies of Japanese and U.S. firms, Journal of Finance, 53, 879-904.

Esteban, J. and Pérez, O. (2001) Dividend policy European banks, Programa Interuniversitario de Doctorado 'Nuevas Tendencias en Dirección de Empresaś' Universidad de Burgos, Universidad de Salamanca, Universidad de Valladolid.

Fama, E. (1974) The empirical relationship between the dividend and the investment decisions of firms, American Economic Review, 64, 304-318.

Fama, E. and Babiak, H. (1968) Dividend policy: An empirical analysis, Journal of American Statistical Association, 63, 1132-1161.

Fazzari, S., Hubbard, R. and Petersen, B. (1988) Financing constraints and corporate investment, Brookings Paper for Economic Activity, 1, 141-95.

Fleming, G., Heaney, R. and McCosker, R. (2005) Agency costs and ownership structure in Australia, Pacific-Basin Finance Journal, 13, 29-52.

Gugler, K. (2003) Corporate governance, dividend payout policy, and the interaction between dividends, R\&D, and capital investment, Journal of Banking and Finance, 27, 1297-1321.

Guttman, I., Kadan, O. and Kandel, E. (2008) A theory of dividend smoothing, Working Paper, Stanford University, United States of America.

Hallock, K. and Mashayekhi, F. (2006) Are formal corporate news announcements still newsworthy? evidence from three decades of US data on earnings, splits, and dividends, Working Paper, Cornell University, United States of America.

Huang, H. (2001a) Bayesian analysis of the dividend behavior, Applied Financial Economics, 11, 333-339.

Huang, H. (2001b) Bayesian analysis of SUR Tobit model, Applied Economics Letters, 8, 617-622.

Jenog, J. (2008) An investigation of dynamic dividend behavior in Korea, Working Paper, Korea University, Korea. 
John, K. and Knyazeva, A. (2008) Payout policy, agency conflicts, and corporate governance, Working Paper, University of Rochester, United States of America.

John, K., and Williams, J. (1985) Dividends, dilution and taxes: a signaling equilibrium, Journal of Finance, 40, 1053-1070.

Kaplan, S. and Zingales, L. (1997) Do financing constraints explain why investment is correlated with cash flow?, Quarterly Journal of Economics, 112, 169-215.

Kim, B., and Maddala, G. (1992) Estimation and specification analysis of models of dividend behavior based on censored panel data, Empirical Economics, 17, 111124.

Knyazeva, A. (2008) Which companies deliver on the dividend promise? new evidence on dividend smoothing and dynamic dividend behavior, Working Paper, University of Rochester, United States of America.

La Porta, R., Lopez de Silanes, F., Shelifer, A. and Vishny, R. (1998) Law and finance, Journal of Political Economy, 106, 1113-1155.

Leary, M. and Michaely, R. (2009) Why firms smooth dividends: empirical Evidence", Working Paper, Cornell University, United States of America.

Lintner, J. (1956) Distribution of income of corporations among dividends, retained earnings and taxes, American Economic Review, 46, 97-113.

Michaely, R. and Roberts, M. (2007) Dividend smoothing, agency costs, and information asymmetry: lessons from dividend policies of private firms, Working Paper, Cornell University, United States of America.

Miller, M. and Modigliani, F. (1961) Dividend policy, growth, and the valuation of shares, Journal of Business, 34, 411-433.

Mohamed, E., Oyelere, P. and Al Jifri, K. (2009) State corporate governance in Oman: progress has been rapid, sophistication has increased, but there is still room for improvement, Journal of Taxation and Regulation of Financial Institutions, 22, 70-78.

Naceur, S., Doaid, M. and Belanes, A. (2006) On the determinants and dynamics of dividend policy, International Review of Finance, 6, 1-23.

Omet, G. (2004) Dividend policy behavior in the Jordanian capital market, International Journal of Business, 9, 287-299.

Rozycki, J. (1997) A tax motivation for smoothing dividends, The Quarterly Review of Economics and Finance, 37, 563-573.

Saidi, N. and Kumar, R. (2008) Corporate Governance in the GCC, Hawkamah Institute for Corporate Governance Paper, UAE. 
